\title{
Shifting Mandates: The Federal Reserve's First Centennial
}

\section{Citation}

Reinhart, Carmen M, and Kenneth S. Rogoff. 2013. Shifting mandates: The Federal Reserve's first centennial. American Economic Review 103, no. 3: 48-54.

\section{Published Version}

doi:10.1257/aer.103.3.48

\section{Permanent link}

http://nrs.harvard.edu/urn-3:HUL.InstRepos:11129184

\section{Terms of Use}

This article was downloaded from Harvard University's DASH repository, and is made available under the terms and conditions applicable to Other Posted Material, as set forth at http:// nrs.harvard.edu/urn-3:HUL.InstRepos:dash.current.terms-of-use\#LAA

\section{Share Your Story}

The Harvard community has made this article openly available.

Please share how this access benefits you. Submit a story.

\section{Accessibility}




\title{
Shifting Mandates: The Federal Reserve's First Centenniali
}

\author{
By Carmen M. Reinhart and Kenneth S. Rogoff*
}

\begin{abstract}
An Act To provide for the establishment of Federal Reserve banks, to furnish an elastic currency, to afford means of rediscounting commercial paper, to establish a more effective supervision of banking in the United States, and for other purposes.
\end{abstract}

Federal Reserve Act, December 23, 1913.

After recurring bouts of financial panics and banking crises, including a particularly severe one in 1907, a clamor arose among policy circles and the business community that the United States was in need of serious banking and currency reform. Part of this reform would be the creation of an institution that would, when the system was threatened with periodic regional or national financial crises, provide the necessary liquidity to support the banks that were in duress - the so-called provision of an elastic currency. As the opening line of the Federal Reserve Act clearly articulates, financial stability took center stage in the initial mandate of the United States' central bank. While the Federal Reserve Act defined the supervisory duties of the Fed, there is no mention of a price stability mandate in the original version of the legislation. Indeed, the word inflation does not appear at all in the document. A full employment macroeconomic goal is not even remotely alluded to.

It is probable that in 1913, while financial panics were not uncommon, high inflation was still largely seen by the founders of the Fed as a relatively rare phenomenon associated with

\footnotetext{
* Reinhart: Minos A. Zombanakis Professor of the International Financial System, Kennedy School of Government, Harvard University, 79 JFK Street, Cambridge, MA 02138 (e-mail: Carmen_Reinhart@harvard.edu); Rogoff: Thomas D. Cabot Professor of Public Policy, Economics Department, Harvard University, Littauer Center 216, Cambridge, MA 02138 (e-mail: krogoff@ harvard.edu). The authors would like to thank Charles Plosser and Vincent Reinhart for useful comments.

$\uparrow$ To view additional materials, and author disclosure statement(s), visit the article page at http://dx.doi.org/10.1257/aer.103.3.48.
}

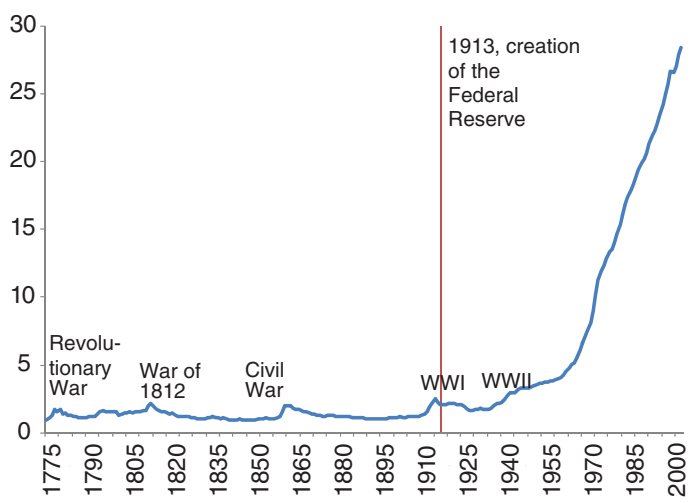

Figure 1. Consumer Price Index, United States, 1775-2012 (LEVEL, $1775=1$ )

Sources: Bureau of Labor Statistics, Historical Statistics of the United States, and Reinhart and Rogoff (2009).

wars and their immediate aftermath. Figure 1 plots the US price level from 1775 (set equal to one) until 2012. In 1913 prices were only about 20 percent higher than in 1775 and around 40 percent lower than in 1813, during the War of 1812. Whatever the mandates of the Federal Reserve, it is clear that the evolution of the price level in the United States is dominated by the abandonment of the gold standard in 1933 and the adoption of fiat money subsequently. One hundred years after its creation, consumer prices are about 24 times higher than what they were in 1913. This pattern, in varying orders of magnitude, repeats itself across nearly all countries.

In the next section, we sketch how the mandates of the Fed have morphed over time from a predominantly financial stability goal at its outset in 1913, to facilitating fiscal financing during World War II and its aftermath, to a higher emphasis on inflation stabilization and price stability from the late 1970s until the 2007 subprime crisis. Now, possibly, the pendulum is swinging back to place a greater weight on its initial mandate of financial stability, which policymakers and financial markets had come to take for granted during the postwar era. 
In Section II we present evidence to suggest that across all these regimes, whether the mandate was financial stability, low inflation and full employment, or public debt monetization, short-term policy interest rates (prices) are usually not a sufficient statistic to characterize monetary or liquidity conditions at a point in time. As recently stressed in Schularick and Taylor (2012), we emphasize credit developments (quantities) to supplement interest rates and provide a more comprehensive view of financial conditions.

We conclude by arguing that multiple policy goals call for multiple instruments. Policies, such as changes in reserve and margin requirements and a variety of credit measures that have been discarded as antiquated, should be a part of the toolkit of the central bank in the United States and other advanced economies. These instruments have continued to play a central role in defining monetary policy in many emerging markets to the present day. In principle, of course, other regulators can and should play a role, but the experience of overly narrowing the central bank's purview has not proved an entirely successful one.

\section{Targets and Instruments: A 100-Year Timeline}

At the risk of a gross simplification, the Federal Reserve's first centennial can be roughly divided into three subperiods. From its creation in 1913 until the 1930s its primary mandate was financial stability. The second phase was an era of "fiscal dominance" from the outset of World War II until the late 1970s (the 1951 Fed-Treasury accord notwithstanding), when the Fed facilitated fiscal financing in varying degrees, albeit often in the name of employment. From 1979, beginning with an aggressive inflation stabilization plan until the crisis of 2007, the third phase, (an independent) Fed was guided by a mandate of price stability and macroeconomic stabilization. It is premature to characterize the fourth phase ushered in by the 2007 crisis. Table 1, which shades the eras, provides highlights of this timeline and guides our discussion.

Our aim is not merely to recap the past but to draw some lessons for the future and better understand the present. With a cumulative output collapse of 31 percent from 1929 until 1933 and the number of banks operating cut roughly in half over 1925-1933, it is safe to conclude that the early Federal Reserve failed miserably at meeting its initial mandate of financial stability. This failure led to the establishment of the Federal Deposit Insurance Corporation (FDIC) and its supervision mandate. During the course of the 1930s a relatively laissez-faire approach to financial markets (both domestically and internationally) gave way to a significant increase in the regulation of the financial industry and to the erection of barriers to the international flow of financial capital that were the hallmark of the now-defunct gold standard. This wave of financial deglobalization, while somewhat more extreme, is not unlike the trends that have been set in motion by the recent crisis, especially in Europe. During this first era, the Fed did have multiple instruments at its disposal apart from setting interest rates. Unfortunately, some of these instruments of policy were employed procyclically. For example, reserve requirements were doubled (from 13 to 26 percent) between 1935 and 1937 in the midst of the Depression (see Table 1).

While substantial public debts were accumulated during the 1930s (see Reinhart and Rogoff 2009), there is nothing in US history to match the debt build up that would accompany WWII. For about four decades (1939-1978) the Fed would remain largely subservient to the Treasury. Interest rates were capped, credit ceilings remained in place through the early 1950 s, and financial repression domestically and abroad ruled the day. Whatever distortions these policies may have led to in terms of the misallocation of resources, it is important to note that from 1945 until the late 1970s there were no systemic banking crises in the United States or elsewhere. Such a long uninterrupted period of tranquility was a new phenomenon in the history of finance. Ultimately, sustained monetary policy accommodation combined with adverse supply shocks gave way to persistent inflation (see Figure 1) and ushered in the more recent era of an independent Fed with the restoration of price stability as its main mandate. . $^{1}$

To understand the shift in mandate and focus of the Federal Reserve during 1979-2007, it is

\footnotetext{
${ }^{1}$ It has to be noted that what was achieved in the era of the "great moderation" was inflation stability—not price stability-as Figure 1 makes plain.
} 
Table 1-Selected Timeline: 1913-2012

\begin{tabular}{|c|c|c|c|c|c|}
\hline $\begin{array}{l}\text { Selected } \\
\text { years }\end{array}$ & $\begin{array}{c}\text { Legislative/regulation/ } \\
\text { other }\end{array}$ & $\begin{array}{l}\text { Financial } \\
\text { crisis }\end{array}$ & $\begin{array}{c}\text { Inflation } \\
\text { performance }\end{array}$ & $\begin{array}{c}\text { Real } \\
\text { interest rates }\end{array}$ & $\begin{array}{l}\text { Other } \\
\text { policy }\end{array}$ \\
\hline 1913 & Fed created & & & & \\
\hline $1914-1918$ & WWI- capital controls & Equity crash & Peak $18 \%$ & $-4.2 \%$ average & War bond drive \\
\hline 1919-1929 & Liberal financial markets & Real estate crash & $1.4 \%$ average & $3.7 \%$ average & \\
\hline 1931 & 2,031 bank closures & Crisis peak & $-9 \%$ & $11.6 \%$ & \\
\hline $1932-1933$ & $\begin{array}{l}\text { Glass-Steagall, FDIC } \\
\text { created, end of gold } \\
\text { standard, onset of capital } \\
\text { controls }\end{array}$ & & -5 to $-10 \%$ & $6.8-12.2 \%$ & $\begin{array}{c}\text { 1935-1937, reserve } \\
\text { requirements } \\
\text { doubled }\end{array}$ \\
\hline 1939-1945 & $\begin{array}{l}\text { WWII- Bretton Woods } \\
\text { agreement, 1944-1945 }\end{array}$ & & Peak $12.9 \%$ & & $\begin{array}{l}\text { War bond drive \& } \\
\text { credit controls }\end{array}$ \\
\hline $1945-$ & $\begin{array}{l}\text { Financial repression \& } \\
\text { capital controls, heavy } \\
\text { regulation of finance, } \\
1945-1980\end{array}$ & $\begin{array}{l}\text { Longest hiatus in } \\
\text { crises, US \& } \\
\text { worldwide, } \\
1945-1980\end{array}$ & & $-0.4 \%$ average & Ceiling on t-bills \\
\hline 1951 & Fed-Treasury Accord & & & & Fed independence \\
\hline 1970s & Oil shocks & & Peak $14 \%$ & -2.8 to $2 \%$ & \\
\hline 1978-1979 & $\begin{array}{l}\text { Humphrey Hawkins Full } \\
\text { Employment Act }\end{array}$ & & & $0 \%$ average & $\begin{array}{c}\text { Stabilization starts } \\
\text { October } 1979\end{array}$ \\
\hline 1980-1986 & $\begin{array}{c}\text { Financial liberalization- } \\
\text { interest ceilings } \\
\text { eliminated }\end{array}$ & $\mathrm{S} \& \mathrm{~L}$ crisis & 13.5 to $1.9 \%$ & $4.5-6 \%$ & $\begin{array}{c}\text { Inflation } \\
\text { stabilization }\end{array}$ \\
\hline $2000-$ & $\begin{array}{l}\text { Treasury purchases by } \\
\text { foreign central banks } \\
\text { skyrocket }\end{array}$ & $\begin{array}{l}\text { Subprime onset } \\
2007\end{array}$ & $2.5 \%$ average & $\begin{array}{l}2 \% \text { average } \\
1981-2007\end{array}$ & \\
\hline 2008-2012 & $\begin{array}{l}\text { QEs, Dodd-Frank, return } \\
\text { of financial repression? }\end{array}$ & & & $-1.6 \%$ average & Directed credit \\
\hline
\end{tabular}

Sources: Meltzer (2003), Reinhart and Rogoff (2009).

necessary to briefly review key features of its prior incarnations. The fact that the colossal failure of the 1930s gave rise to other institutions that took on supervisory responsibilities helped pave the way, in principle, for the Fed to focus more of its energy on the goal of inflation and countercyclical macroeconomic stabilization in the modern era. It is notable that post-WWII, the highly regulated financial markets with their intense home bias gave rise to only a few crises in advanced economies (especially in comparison to the panic-ridden prewar era). This quietus facilitated the view in both academic and policy circles that advanced economies had outgrown severe financial crises, and that these were a phenomenon confined to the emerging markets. In an environment where other supervisory insti- tutions and financial markets were thought to be monitoring risk, the Fed mandate eventually narrowed to emphasize inflation and unemployment. As the mandate became more focused, older instruments of monetary policy were discarded as distortionary and obsolete. Reserve and margin requirements as well as other policies designed to curb credit growth and leverage were relegated to history. Interest rate policy and communications strategies became the sole instruments of monetary policy.

In the next section, we suggest that irrespective of the changes in the Fed's mandates, credit aggregates merit a larger role in setting policy and gauging financial conditions-especially if financial stability regains a more prominent role in policy design. 


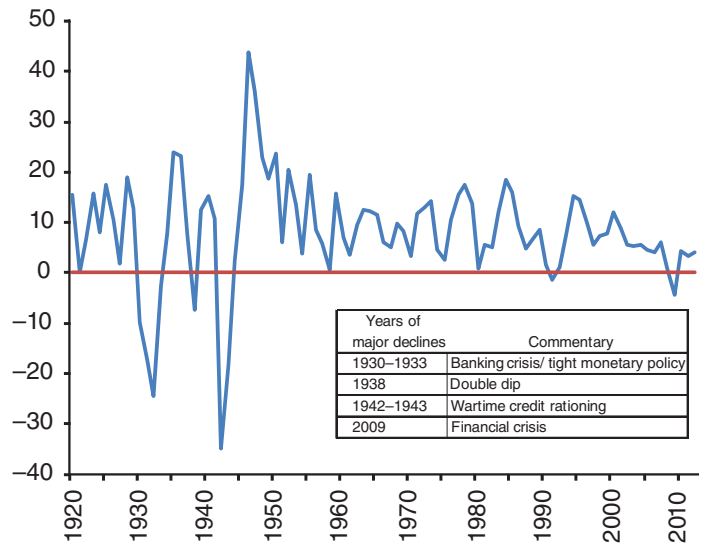

Figure 2. Change in Total Consumer Credit Outstanding, 1920-2012

(end-of-period, annual percent change)

Sources: Board of Governors of the Federal Reserve System, Historical Statistics of the United States, and Reinhart and Rogoff (2009).

\section{Interest Rates and Credit}

In the past three decades, the behavior and evolution of private credit has received comparatively little attention as an indicator of aggregate demand, inflationary pressures, or as a potential early warning of financial vulnerability. On the latter score, the key role of credit booms in anticipating financial crises in advanced economies since the late nineteenth century is extensively documented by Schularick and Taylor (2012). The evidence for emerging markets presented in Mendoza and Terrones (2012) is equally compelling; as they observe, not every credit boom ends in crisis, but nearly all crises are preceded by credit booms.

Here we present evidence that across time and regimes ranging from the relatively globalized and laissez-faire financial system of the "roaring 1920s" and pre-2007 crisis to the postWWII financial repression era, the behavior of credit has provided valuable and complementary information about the "de facto" stance of monetary policy (or, more accurately, monetary or liquidity conditions) to that incorporated in the short-term policy interest rate. To clarify, we follow the widely accepted convention that the intent to tighten/ease monetary policy is signaled primarily through an increase/decrease in policy interest rate(s) and that this intent defines "de jure" policy. Along those lines, Romer and Romer (1989) are more concerned with defining policy intent. Here we suggest that credit conditions may reenforce the changes in the policy interest rate at a given point in time, or they may counteract those changes. Thus de facto monetary or liquidity conditions may on occasion substantially differ from what might be perceived based on interest rates alone.

\section{A. An Illustration for Consumer Credit: 1919-2012}

Given the depth of its equity, corporate bond, and commercial paper markets, the United States is considered to be the least bank-dependent economy in the world, at least when it comes to corporate finance. For households, however, banks play a dominant role in the United States as they do in other countries. Hence, our focus on consumer credit here. ${ }^{2}$ With a secular shift to an urban society since the early twentieth century, household credit as a share of disposable income has risen steadily year after year, as part of what is often called financial deepening. As Figure 2 shows, since 1919 the nominal stock of consumer credit outstanding has shown substantial annual declines during only three episodes: the collapse of the banking system during the Great Depression, the credit rationing during World War II, and in 2009 at the height of the Subprime Crisis. While the most recent credit contraction is not as severe as the wartime or Depression credit collapses, a 4.3 percent decline in nominal consumer credit in 2009 is far removed from the 8.2 average yearly percent increase recorded over 1919-2012.

Since, as shown in Figure 2, only nine of the 93 annual observations show a contraction in consumer credit (and these nine observations are clustered in three episodes), it will be more informative to describe credit conditions in terms of whether credit growth is accelerating or decelerating in a particular year. In addition, to describe whether monetary policy is tighter or more accommodative, we focus on the basis point change in interest rates in a given year.

\footnotetext{
${ }^{2}$ Consumer credit was also the main target of the credit ceiling policies of the $1940 \mathrm{~s}-1980$.
} 
Table 2-Changes in Policy Interest Rates and Changes in Consumer Credit, 1921-2012

\begin{tabular}{|c|c|c|}
\hline Interest rate/credit combination & Number of years & Share of years \\
\hline $\begin{array}{l}\text { unambiguous easing } \\
\text { Declining interest rates and accelerating credit growth }\end{array}$ & 8 & 8.7 \\
\hline $\begin{array}{l}\text { mixed easing } \\
\text { Declining interest rates and unchanged/decelerating credit growth }\end{array}$ & 25 & 27.2 \\
\hline $\begin{array}{l}\text { neutral to easier } \\
\text { Unchanged interest rates and accelerating credit growth }\end{array}$ & 12 & 13.0 \\
\hline $\begin{array}{l}\text { neutral } \\
\text { Unchanged interest rates and credit growth }\end{array}$ & 2 & 2.2 \\
\hline $\begin{array}{l}\text { neutral to tighter } \\
\quad \text { Unchanged interest rates and decelerating credit growth }\end{array}$ & 11 & 12.0 \\
\hline $\begin{array}{l}\text { mixed tightening } \\
\text { Rising interest rates and unchanged/accelerating credit growth }\end{array}$ & 21 & 22.8 \\
\hline $\begin{array}{l}\text { unambiguous tightening } \\
\text { Rising interest rates and decelerating credit growth }\end{array}$ & 13 & 14.1 \\
\hline $\begin{array}{l}\text { memorandum item } \\
\text { Total number of years for which there is credit and policy rate data }\end{array}$ & 92 & 100 \\
\hline
\end{tabular}

Sources: Board of Governors of the Federal Reserve System, Historical Statistics of the United States, and Reinhart and Rogoff (2009).

Since 1955 we use the federal funds rate, while the discount rate fills that role over 1913-1954.

Our aim is to assess year by year whether the signals coming from credit tend to reenforce or offset the signals coming from interest rates. A year when the policy rate is declining and credit growth is accelerating is counted as an observation of unambiguous easing as both indicators of monetary conditions reenforce. With interest rates being the primary instrument, a year in which rates are falling but credit growth is unchanged or decelerating is counted as mixed easing. A neutral to easier observation comes from a year where the policy interest rate is unchanged but credit growth is accelerating. Symmetric definitions apply for tightening.

The results of this accounting exercise for 1921-2012 (92 years) are presented in Table 2.

Prior to examining the results, it is important to highlight some of the limitations of the exercise. First, whether credit is accelerating or decelerating, each data point reflects a final outcome; further analysis would be required to sort out whether the observed outcome primarily owes to supply or demand shifts. Second, we look at credit momentum and interest rate changes to characterize a particular year; their dynamic relationship is not explored. It is to be expected that sometimes rising interest rates will show up only in a deceleration in credit and only in the following year. Similarly, a credit boom in an overheated economy may lead to a deliberate policy tightening and rising policy interest rates that do not immediately gain traction in credit markets. Third, while interest rates are taken to be the primary instrument (really the only instrument in the post-1980s financial liberalization period), this was not always the case. Reserve requirement changes were also a part of the policy toolkit in an earlier era. Even more explicitly impacting credit was the past use of credit controls, as highlighted in Table 1. Credit controls were used during World War II, also in its immediate aftermath, and most recently in 1980 under President Carter. ${ }^{3}$

With these caveats in mind, we turn to the results presented in Table 2, which distributes the 92 annual observations into the seven buckets that range from unambiguously tight to unambiguously easy monetary or liquidity conditions. Note that less than a fourth ( 23 percent) of the observations fall into the two extreme unambiguous categories, where interest rates and credit

\footnotetext{
${ }^{3}$ Interestingly, the use of credit controls following WWII and again in 1980 was decidedly motivated by inflation stabilization efforts rather than by concerns about rising leverage and its impact on financial stability.
} 
both send the same signal. Furthermore, this pattern does not vary across regimes, whether the regime is defined by the primary goal of the Federal Reserve at the time or by the degree of international capital mobility and/or domestic financial regulation.

Over a quarter of the time, when declining interest rates were signaling a more accommodative monetary policy stance, credit was decelerating. This situation characterizes most of the post-2007 crisis years. In both 2008 and 2009 interest rates fell sharply, yet, quantitative easing notwithstanding, consumer credit growth decelerated sharply. As noted earlier, one cannot definitely apportion the observed deceleration in credit between, for example, a tightening of lending standards versus weak demand due to weak consumer balance sheets and recession.

More than 23 percent of the time, rising policy interest rates are not accompanied by slowing credit (i.e., mixed tightening category). Several observations from the high inflation years of the 1970s fall in this bucket. Perhaps it owes to interest rate increases that were insufficient, only following or accommodating the rapid rise of inflation at that time. By contrast, Table 3, which lists the years where credit and the policy rate gave reenforcing signals, flags the famous Volcker anti-inflation tightening that began in October 1979. The double signal also captures the now notorious procyclical tightening in 1931 that involved a 150 basis point increase in the discount rate alongside a 17 percent deceleration in credit growth, which also makes the list. Notably, all the dates of unambiguous tightening map well onto the NBER's dating of recessions, as these followed the policy change within one or two years. Years of unambiguous easing include 1933 and 1934 after the abandonment of the gold standard, 1983 (the Fed actually began lowering rates in August 1982), and the early 1990s. Recent years do not figure in this list.

\section{Policy Implications: Back to the Future}

In the post-crisis environment, the Federal Reserve is likely to attach a greater weight to a financial stability objective than it had prior to the crisis-at least for some time. Since the price stability and full employment goals have not been set aside, we call attention to the fact that multiple policy goals usually call for multiple instruments. Yet over the past three decades
Table 3-Years Where Credit and InTERest Rates SigNALS REENFORCED

\begin{tabular}{ll}
\hline unambiguous easing years & $1922,1933,1934,1971$, \\
& $1976,1983,1992,1993$ \\
& \\
unambiguous tightening & $1926,1931,1953,1956$, \\
years & $1957,1966,1969,1974$, \\
& $1979,1980,1995$ and 2005
\end{tabular}

Source: Authors' calculations.

both the academic literature and the policy practice have increasingly drifted to a world view where the short-term policy rate is a sufficient policy instrument. The theoretical underpinnings supporting that view usually assume complete markets, an assumption that is particularly at odds with a post-crisis environment riddled with a broad assortment of frictions arising from both market failures and a steady stream of complex regulatory changes set in motion by the crisis. In that environment, policies such as changes in reserve and margin requirements and a variety of credit measures that have been discarded as antiquated should again be part of the toolkit of central banks in the United States and other advanced economies, at least until a far more robust and effective regulatory superstructure is firmly in place. As just one example, if the Federal Reserve had greater capacity to impose reserve requirements, today's quantitative easing policies would hold less exit risk, and correspondingly could be employed more aggressively.

\section{REFERENCES}

Meltzer, Allan H. 2003. A History of the Federal Reserve. Volume 1. 1913-1951. Chicago: University of Chicago Press.

Mendoza, Enrique G., and Marco E. Terrones. 2012. "An Anatomy of Credit Booms and their Demise." National Bureau of Economic Research Working Paper 18379.

Reinhart, Carmen M., and Kenneth S. Rogoff. 2009. This Time Is Different: Eight Centuries of Financial Folly. Princeton: Princeton University Press.

Romer, Christina D., and David H. Romer. 1989. "Does Monetary Policy Matter? A New Test in the Spirit of Friedman and Schwartz." In NBER 
Macroeconomics Annual 1989. Vol. 4, edited by Olivier Jean Blanchard and Stanley Fischer, 121-70. Cambridge, MA: MIT Press.

-Schularick, Moritz, and Alan M. Taylor. 2012.
"Credit Booms Gone Bust: Monetary Policy, Leverage Cycles, and Financial Crises, 1870-2008." American Economic Review 102 (2): 1029-61. 